\title{
ASAS KEKELUARGAAN SEBAGAI NILAI KONSTITUSIONAL DALAM KOPERASI DAN PERSEROAN TERBATAS
}

\author{
Oleh: Indra Afrita dan Yalid \\ Alamat: Fakultas Hukum Universitás Lancang Kuning. Jl. Yos Sudarso km 8, \\ Rumbai Pekanbaru. Email: yalid11@yahoo.co.id
}

\begin{abstract}
Abstrak
Asas kekeluargaan dalam Undang-Undang Nomor 17 Tahun 2012 tentang Perkoperasian (Undang-Undang Perkoperasian) relevan dengan usahanya yang mengutamakan kemakmuran anggota, bukan kemakmuran perseorangan. Hal ini terlihat dalam ketentuan Undang-Undang Perkoperasian yang secara konsisten berdasarkan nilai dan prinsip kekeluargaan sebagaimana ditentukan Pasal 5 Ayat (1) huruf a mengenai hak dan kewajiban anggota dan Pasal 35 mengenai sistem musyawarah dalam pengambilan keputusan. Sistem musyawarah ini lebih menempatkan kepentingan bersama daripada kepentingan individu. Sistem musyawarah yang bersumber dari asas kekeluargaan memberikan alternatif yang lebih baik. Sedangkan Undang-Undang Nomor 40 Tahun 2007 tentang Perseroan Terbatas (Undang-Undang Perseroan Terbatas), bila amati ternyata tidak berbeda prinsipnya dengan Kitab Undang-Undang Hukum Dagang mengenai hak dan wewenang pemegang saham maupun dalam pengaturan berkenaan dengan RUPS. Sistem qourum dan sistem one share one vote ternyata lebih dekat kepada sistem individualistik lawan dari kekeluargaan. Sistem one share one vote memungkinkan mayoritas tidak menyetujui ide minoritas, meskipun ide itu baik. Selain itu, dibukanya pasar uang dan modal memungkinkan perusahaan yang berbentuk perseroan terbatas dimiliki orang-orang yang tidak saling mengenal maka tidak akan mudah terlaksana semangat kekeluargaan dalam mengelola perusahaan. Oleh karena itu, disarankan penyesuaian asas kekeluargaan dengan adanya sistem qourum dan sistem one share one vote dan penyelarasan asas kekeluargaan berkaitan dengan dibukanya pasar uang dan modal sebagai salah satu penyertaan modal dan kepemilikan dalam perseroan terbatas.
\end{abstract}




\begin{abstract}
The cooperative principle in Law Number $17 / 2012$ on Cooperation was relavant to the effort of improving the properity of the members not induvidual one. It was shown form the rules in Cooperation Law which are consistent with the cooperative principle in section 5(1a) concerning right and obligation of the member and section35 concerning acclamation in decision making. Acclamation sourced form the cooperative principle. It was considered as the best way. On the contrary, Law Number 40/2007 on Limited Company was in line with the principle in Commercial Code which stressed o the right and power of the share holder as well as the rule in the share holders conference. Quorum and one share one vote system were close to individual approach in which they were contrast with the cooperative principle. One share one vote system allowed the majority toignore the opinion of the minority though the majority ideaswere not always the best. Besides, the opening of market of security made the limited company was owned by the persons who were not knowns each other. Therefore, it was impossible to implement the cooperative principlein managing the company. This article suggested to reconstruct the quorum and one share one vote system with the spirit of the cooperative principle related with the opening of security market and invesment in limited company.
\end{abstract}

Kata kunci: asasi kekeluargaan, koperasi, perseroan terbatas

\section{Pendahuluan \\ Dunia usaha merupakan kegiat- an perekonomian yang amat penting dalam kehidupan suatu negara. Selain itu, dalam kehidupan sehari-hari kegiatan dunia usaha menjadi tumpuan bagi masyarakat khususnya para pengusaha dan pekerja untuk mendapatkan rezeki berupa keuntung- an atau upah.}

Agar dunia usaha tertata dengan baik maka harus didukung dengan sarana penunjang berupa tatanan hukum yang dapat mendorong, menggerakkan dan mengendalikan dunia usaha itu. ${ }^{1}$ Karenanya Pemerintah selaku regulator berkewajiban mengarahkan, membimbing, melindungi agar kegiatan dunia usaha dapat serasi dalam satu kesatuan menuju

\footnotetext{
${ }^{1}$ Badan Pembinaan Hukum Nasional, Laporan Akhir Tim Analisis dan Evaluasi Hukum tentang Bentuk-Bentuk Badan Usaha di Luar Perusahaan Terbatas dan Koperasi, (Jakarta: Badan Pembinaan Hukum Nasional, 2003), hlm. 15.
} 
terçapainya pembangunan nasional. ${ }^{2}$ Selaku regulator, Pemerintah telah menata aturan hukum sebagai wadah usaha agar dapat mendorong, menggerakkan dan mengendalikan dunia usaha. Sebagian di antaranya adalah koperasi dan perseroan terbatas. Koperasi diatur dalam UndangUndang Nomor 17 Tahun 2012, sedangkan perseroan terbatas diatur dalam Undang-Undang Nomor 40 Tahun 2007.

Secara historis, tatanan hukum perseroan terbatas sebelum lahirnya undang-undang perseroan terbatas berasal dari Belanda. Saat Belanda memerintah telah diperkenalkan perseroan terbatas dengan istilah Naamloze Vennotschap disingkat NV. I.G. Rai Widjaya mengemukakan bahwa sebagian bentuk-bentuk badan usaha di Indonesia merupakan warisan masa lalu (Belanda). ${ }^{3}$ Sebutan naamloze dalam arti tanpa nama dişebabkan NV itu tidak mempunyai nama seperti firma pada umumnya, juga tidak mempergunakan salah satu nama dari anggota perseronya. ${ }^{4}$ Menurut Rudhi Prasetya, istilăh Perseroan Terbatas yang digunakan Indonesia sebenarnya mengawinkan antara sebutan yang digunakan hukum Inggris dan hukum Jerman. Di satu pihak ditampilkan segi sero atau sahamnya, tetapi sekaligus di sisi lain juga ditampilkan segi tanggung jawabnya yang terbatas. ${ }^{5}$

Perseroan terbatas jelas memiliki ciri-ciri yang berbeda ${ }^{6}$ dengan koperasi. ${ }^{7}$ Perbedaan koperasi dengan perseroan terbatas terletak pada sistem nilai etis yang melandasi kehidupannya dan terjabar dalam prinsip-prinsipnya yang kemudian berfungsi sebagai norma-norma etis yang mempolakan tata laku koperasi sebagai ekonomi. ${ }^{8}$ Tatanan hukum koperasi dan perseroan terbatas

${ }^{2}$ Ratnawati Prosodjo, RUU tentang Usaha Perseorangan dan Badan Usaha Bukan Badan Hukum, Makalah Disampaikan pada Acara Sosialisasi RUU Usaha Perseorangan dan Badan Usaha Bukan Badan Hukum, Diselenggarakan oleh Direktorat Jenderal Peraturan Perundang-undangan Departemen Hukum dan HAM RI di Hotel Kartika ChandraJakarta, 2007, hlm. 8.

${ }^{3}$ I.G. Rai Widjaya, Hukum Perusahaan, (Jakarta: Megapoin, 2003), hlm. 1.

${ }^{4}$ Achmad Ichsan, Dunia Usaha Indonesia, (Jakarta: Pradnya Paramita, 1986), hlm. 345.

${ }^{5}$ Rudhi Prasetya, Kedudukan Mandiri Perseroan Terbatas, (Bandung: Citra Aditya Bakti, 1996), hlm. 2.

${ }^{6}$ Chatamarrasjid, Menyikapi Tabir Perseroan Terbatas (Piercing The Corporate Veil) Kapita Selekta Hukum Perusahaan, (Bandung: Citra Aditya, 2000), hlm. 48.

7 Ibid.

${ }^{8}$ Fray dalam Sri Edi Swasono, Membangun Sistem Ekonomi Nasional, Sistem Ekonomi dan Demokrasi Ekonomi, (Jakarta: UI Press, 1987), hlm. 158. 
mestilah sejalan dengan landasan filosofis di Indonesia, yakni Pancasila.

Nilai konstitusional UUD 1945 (hasil amandemen) Bab XIV tentang Perekonomian Nasional dan Kesejahteraann Sosial, diatur dalam Pasal 33 Ayat (1) yang isinya menyatakan bahwa perekonomian disusun sebagai usaha bersama berdasarkan atas asas kekeluargaan. Menurut Sri Edi Swasono, terkait Ayat (1) Pasal 33 UUD 1945 perkataan disusun artinya direstruktur. Seorang strukturalis pasti mengerti arti disusun dalam konteks restrukturisasi ekonomi, mengubah ekonomi kolonial menjadi ekonomi nasional, menghilangkan subordinasi ekonomi (yang tidak emancipatory) dan menggantinya dengan demokrasi ekonomi (yang participatory dan emancipatory). ${ }^{9}$

Menurut Emil Salim, secara konsepsional sistem ekonomi Pancasila sebagaimana termaktub dalam UUD 1945 Pasal 33, dasar demokrasi ekonomi itu diutamakan kemakmuran masyarakat, bukan kemakmuran orang perorang. Oleh sebab itu, perekonomian disusun sebagai usaha bersama berdasarkan asas kekeluargaan dan bangunan perusahaan yang sesuại, yakni koperasi bukan bentuk yang lain. ${ }^{10}$

Asas kekeluargaan terjelma dalam empat bentuk. Pertama, mengembangkan koperasi di antara buruh dan karyawan. Koperasi adalah wahana untuk meninggikan kesejahteraan buruh dan meningkatkan kecerdasannya lewat pendidikan buruh dan sebagainya. Kedua, menumbuhkan hubungan perburuhan (industrial relation) yang sesuai dengan asas-asas kekeluargaan, yakni antara buruh dan pengusaha terjalin semangat kekeluargaan. Ketiga, dalam bentuk lain dikemudian hari perusahaan swasta akan menjual sebagian sahamnya kepada masyarakat juga kepada buruh dan karyawannya. Sedangkan dalam koperasi simpan pinjam di antara buruh/ karyawannya dapat menjadi pemegang saham. Keempat, buruh dapat memperoleh hak untuk ikut mengatur perusahaan tempat ia bekerja. ${ }^{11}$

Atas dasar itu maka asas kekeluargaan tidak semata-mata bersifat materialistis dan individualistis. Undang-undang perseroan terbatas tidak konsisten menerapkan asas kekeluargaan. Meskipun

${ }^{9}$ Sri Edi Swasono, "Pasal 33 UUD 1945 Harus dipertahankan, Jangan Diubah, Boleh ditambah Ayat," Jurnal Perencanaan Pembangunan, No. 26, Tahun 2002, hlm. 35.

${ }^{10}$ Emil Salim dalam Pemikiran dan Permasalahan Ekonomi di Indonesia (buku 3 1966-1982) Paruh Pertama Ekonomi Orde Baru, (Yogyakarta: Kanisius kerja sama dengan ISEI, 2005), hlm. 66.

${ }^{11}$ Lihat http://desmaputrii.blogspot.com/2012/03/tugas-softskill-minggu-313.html, diakses tanggal 5 Maret 2013. 
konsideran Undang-Undang Nomor 40 Tahun 2007 pada huruf c secara terang menjadikan asas kekeluargaan sebagai asasnya. Namun, asas kekeluargaan dalam undang-undang perseroan terbatas hanya dimaksudkan bahwa dalam melakukan pengurusan perusahaan, direksi, pemegang saham dan komisaris serta karyawan yang bekerja dalam perusahaan dituntut untuk membangun sistem kekeluargaan sebagai bangsa Indonesia dengan menghormati dan menjunjung tinggi keberagaman. ${ }^{12}$ Fenomena ketidakkonsistenannya itu sangat dimungkinkan, karena pemilik perseroan terbatas adalah pemegang saham (individual) bukan dimiliki secara kebersamaan (kekeluargaan). Asas kekeluargaan dapat digambarkan sebagai sebuah asas yang memiliki substansi, yakni kebersamaan, idealis keadilan, persamaan hak, gotongroyong, menyeluruh, dan nilai-nilai kemanusiaan". ${ }^{13}$

Dapat digarisbawahi bahwa asas kekeluargaan sebagai nilai konstitusional tidak dapat dikesampingkan dalam kedua tatanan hukum, baik koperasi maupun perseroan terbatas. Pertanyaannya, bagaimanakakah seșungguhnya asas kekeluargaan itu sebagai prinsip hukum yang abstrak diwujudkan dalam peraturan konkrit terhadap koperasi maupun perseroan terbatas? Tulisan ini hendak menganalisis permasalahan tersebut secara komprehensif.

\section{Asas Kekeluargaan dalam Undang- Undang Koperasi}

Istilah asas kekeluargaan secara historis resmi dikemukakan dalam sidang-sidang Badan Penyelidik Usaha-Usaha Persiapan Kemerdekaan Indonesia (BPUPKI) dan Panitia Persiapan Kemerdekaan Indonesia (PPKI), diperlawankan dengan perseorangan. Istilah asas perseorangan adalah istilah Indonesianya untuk pengertian individualistik, sedangkan asas kekeluargaan adalah untuk menerjemahkan istilah integralistik atau non-individualistik. ${ }^{14}$

Asas kekeluargaan tersebut tercantum dalam Pasal 33 Ayat (1) UUD 1945 yang menegaskan bahwa perekonomian disusun sebagai usaha bersama berdasar atas asas kekeluargaan. Menurut Mubyarto,

${ }^{12}$ Naskah Akademik Rancangan Undang-Undang Badan Usaha, hlm. 21.

13 Perkembangan Sistem Perekonomian Indonesia. Lihat http:// putrijulaiha. wordpress.com /2011/04/08/sistem-perekonomian-indonesia/, diakses tanggal 5 Maret 2013.

${ }^{14}$ Padmo Wahjono, Dasar-Dasar Demokrasi Ekonomi Kita, (Suatu Tinjauan dari Segi Ketatanegaraan), Makalah Disampaikan dalam Panel Diskusi di FH-UNTAR, 1990, hlm. 39. 
ketentuan Pasal 33 Ayat (1) UUD 1945 haruslah diakui bahwa pemikir Bangșa ini belum mempunyai kata sepakat. Mohammad Hatta sebagai perumus pasal ini tegas menyebutkan bahwa yang dimaksudkannya adalah sistem perekonomian yang berisi dan berbentuk koperasi. ${ }^{15}$ Mubyarto menjabarkan perkataan koperasi memang tidak disebut dalam Pasal 33, tetapi asas kekeluargaan itu ialah koperasi. Istilah asas kekeluargaan itu adalah taman siswa untuk menentukan bagaimana guru dan murid-murid yang tinggal padanya hidup sebagai satu keluarga. Begitu pulalah hendaknya corak koperasi satu sama lain harus mencerminkan orang-orang bersaudara sekeluarga. ${ }^{16}$

Keadaan konkrit asas kekeluargaan tersebut dalam suatu koperasi tergambar dari penjelasan salah satu koperasi yang menjadi sampel tulisan ini, yakni Koperasi Wanita Beringin. Menurut Ildaini Idrus selaku Ketua Koperasi Wanita Beringin, koperasi sebagai suatu usaha bersama harus mencerminkan ketentuan-ketentuan, seperti lazimnya dalam suatu kehidupan keluarga. Di dalam suatu keluarga tampak bahwa segala sesuatu yang dikerjakan secara bersama-sama ditujukan untuk kepentingan bersama seluruh anggota keluarga. Keadaan ini telah dipraktikan oleh Koperasi Wanita Beringin. Usaha yang dijalankan Koperasi Wanita Beringin dilakukan bersama berdasarkan așaș kẹkeluargaan dan gotong royong. Hal ini mencerminkan semangat kebersamaan. ${ }^{17}$

Sifat kekeluargaan dianggap berlawanan atau paling kurang berlainan jalan dengan sifat perseorangan. Molly Bondan yang banyak bergaul dengan tokoh-tokoh taman siswa, mengutip keterangan para tokoh tersebut menjelaskan bahwa asas kekeluargaan mempunyai dua macam sifat sekaligus, yaitu satu pihak ia mengandung sama rata, sama rasa, persaudaraan dan demokrasi di antara anggotanya. Di pihak lain, ia mengandung suatu sikap tanggung jawab yang mendalam dari pemimpin terhadap anggota dan dari setiap anggota terhadap semua keluarganya terhadap masyarakat di luarnya. Jadi, selain dari persaudaraan, asas kekeluargaan mempunyai sifat-sifat dua arah, yaitu antarsesama

${ }^{15}$ Mubyarto, Keadilan Sosial dan Ekonomi Pancasila, dalam Pemikiran dan Permasalahan Ekonomi di Indonesia dalam Setengah Abad Terakhir, Buku 3 (19661982) Paruh Pertama Ekonomi Orde Baru, (Yogyakarta: Kanisius, 2005), hlm. 76.

${ }^{16} / \mathrm{bid}$.

${ }^{17}$ Wawancara dengan Ildaini Idrus selaku Ketua Koperasi Wanita Beringin, pada tanggal 18 Oktober 2013.

${ }^{18}$ Molly Bondan dalam Tom Gunadi, Sistem Perekonomian Menurut Pancasila dan UUD'45, (Bandung: Angkasa, 1985), hlm. 84. 
anggota dan dari atas ke bawah atau sebaliknyá dari bawah ke atas. ${ }^{19}$

Lebih lanjut Tom Gunadi menyimpulkan bahwa asas kekeluargaan sebagai asas sosial berbeda dengan sistem pendapat sosial yang lahir dari individualisme maupun dari sosialisme radikal. Titik keberangkatannya bukanlah individu yang terisolasi, seperti menurut paham individualisme yang memandang masyarakat sebagai kumpulan individu yang sejak semula dilahirkan bebas, berdiri sendiri, lepas satu sama lain, untuk akhirnya dihubungkan oleh perjanjian atau kontrak sosial. ${ }^{19}$

Asas kekeluargaan dengan asas-asas lain yang diturunkan dari padanya misalnya kewajiban timbal balik dan nilai-nilainya seperti kegotong-royongan serta konsekuensi moralnya yang juga merupakan asas, antara lain tanggung jawab bersama dan tanggung jawab timbal balik, melangkah secara simultan dari persona individual dan masyarakat. ${ }^{20}$

Asas keluargaan yang termaktub dalam UUD 1945 tersebut selanjutnya secara eksplisit terdapat dalam Konsideran Undang-Undang Nomor 17 Tahun 2012 tentang Perkoperasian pada huruf a, yang menyatakan bahwa pembangunan perekonomian nasional bertujuan untuk mewujudkan kedaulatan politik dan ekonomi Indonesia melalui pengelolaan sumber daya ekonomi dạlam suatu iklim pengembangan dan pemberdayaan koperasi yang memiliki peran strategis dalam tata ekonomi nasional berdasarkan asas kekeluargaan dan demókrassi ekonomi dalam rangka menciptakan masyarakat yang maju, adil, dan makmur berlandaskan Pancasila dan UUD 1945.

Kemudian pada Pasal 3 Undang-Undang Nomor 17 Tahun 2012 secara tegas menyebutkan "Koperasi berdasar atas asas kekeluargaan", berkaitan itu nilai yang dan prinsip mendasari kegiatan koperasi adalah kekeluargaan sebagaimana ditentukan pada Pasal 5 Ayat (1) huruf a. Menurut Pasal 5 Ayat (1) huruf a yang dimaksud dengan "kekeluargaan" adalah koperasi dalam melaksanakan usahanya mengutamakan kemakmuran anggota pada khususnya dan masyarakat pada umumnya, bukan kemakmuran orangperseorangan.

Berkaitan dengan hal tersebut, jelaslah asas kekeluargaan dalam Undang-Undang Nomor 17 Tahun 2012 tentang Perkoperasian. Ukuran selanjutnya akan tampak dari pasalpasal dalam Undang-Undang Nomor

19 Djoko Dwiyanto dan Ignas G Saksono, Ekonomi (Sosialis) Pancasila Vs Kapitalisme : Nilai-nilai Tradisional Non Tradisional dalam Pancasila, (Yogyakarta: Keluarga Besar Marhaenis DIY, 2011), hlm. 153.

${ }^{20}$ Tom Gunadi, Sistem Perekonomian ..... Op. Cit., hlm. 85. 
17 Tahun 2012 tentang Perkopérásian yang secara konsiștẹn bẹdásárkan nilai dan prinsip kekeluargaan sebagaimana ditentukan pada Pasal 5 Ayat (1) huruf a terutama menyangkut hak dan kewajiban dari pada anggọta.

Asas kekeluargaan dalam Undang-Undang Nomor 17 Tahun 2012 tentang Perkoperasian menempatkan pengambilan keputusan mesti dilakukan dengan sistem musyawarah (Pasal 35). Sistem musyawarah ini lebih menempatkan kepentingan bersama ketimbang kepentingan individu. Sistem musyawarah yang bersumber dari asas kekeluargaan memberikan alternatif yang ebih baik. Mengacu pada tulisan Bernhard Limbong bahwa prinsip-prinsip yang harus dipenuhi oleh setiap badan usaha yang ingin menamakan dirinya koperasi yang berasas kekeluargaan adalah pertama, adanya pengaturan tentang keanggotaan organisasi yang berdasarkan kesukarelaan, keanggotaan koperasi harus bersifat sukarela. Kedua, adanya ketentuan atau pengaturan tentang persamaan hak antara para anggota. Ketiga, adanya ketentuan atau pengaturan tentang partisipasi dalam ketatalaksanaan dan usaha koperasi. ${ }^{21}$
Selain itu, Sri Edi Swasono menjabarkan lebih lanjut jiwa koperatif berdasarkan asas kekeluargaan, yakni dengan menghayati dari konsepsi triple-co, dengán membentuk suatu mekanisme kooperatif, yaitu coownership (kepemilikan bersama), codetermination (kesetaraan dalam membentuk keputusan), dan coresponsibility (kesertaan dalam bertanggung jawab). ${ }^{22}$

Ketiga point yang dikemukakan Bernhard Limbong di atas sejalan dengan isi pasal-pasal dalam UndangUndang Nomor 17 Tahun 2012 tentang Perkoperasian. Misalnya, pengaturan tentang keanggotaan organisasi yang berdasarkan kesukarelaan diatur pada Pasal 6 Ayat (1) huruf a. Ketentuan atau pengaturan tentang persamaan hak antara para anggota diatur pada Pasal 5 Ayat (1) huruf. Kemudian tentang pengaturan tentang partisipasi dalam ketatalaksanaan diatur pada Pasal 6 ayat (1) huruf $c$.

\section{Asas Kekeluargaan dalam Undang- Undang Perseroan Terbatas}

Pasal 33 Ayat (1) UUD 1945 menegaskan bahwa perekonomian disusun sebagai usaha bersama berdasar atas asas kekeluargaan. Menurut R Wiryono Pasal 33 Undang-

${ }^{21}$ Bernhard Limbong, Ekonomi Kerakyatan dan Nasionalisme Ekonomi, (Jakarta: Pustaka Margaretha, 2011), hlm. 60.

${ }^{22}$ Kata Pengantar Sri Edi Swasono Guru Besar Universitas Indonesia dalam buku Hans H Munkner, 10 Lectures of Co-operatif Law (10 Kuliah Mengenai Hukum Koperasi), Alih Bahasa A Hendriques, (Jakarta: Rekadesa, 2012), hlm. xv. 
Undang Dasar Negara Republik Indonesia Tahun 1945 tidak menutup kemungkinan digunakan terhadap bangun-bangun yang lain selain koperasi. Misalnya terhadap perseroan terbatas, commandiare vennootschap, firma dan lainnya sebagai usaha bersama. Tetapi, dengan syarat bahwa bangun-bangun ini harus mencerminkan adanya asas kekeluargaan. ${ }^{23}$

Salah satu ukuran apakah Undang-Undang Nomor 40 Tahun 2007 tentang Perseroan Terbatas benar-benar dilandasi dengan asas kekeluargaan atau justru dilandasi paham kapitalisme adalah dengan melihat isi dari pasal-pasalnya, terutama yang menyangkut hak-hak dan wewenang yang diberikan kepada pemilik modal atau pemegang saham. Pandji Anoraga mengaitkan asas kekeluargaan terhadap perseroan terbatas dengan pemahaman bahwa dalam perseroan terbatas perlu ditumbuhkan koperasi oleh para buruh, karyawan, dan majikan, sehingga terciptalah asas kekeluargaan di dalam suatu bangunan kapitalistik ini. ${ }^{24}$

Dalam sistem yang dianut Undang-Undang Nomor 40 Tahun 2007 tentang Perseroan Terbatas memberi hak suara berbeda kepada setiap pemegang saham, tergantung kepada jumlah modal yang disertakan dalam perseroan. Semakin banyak modal yang ditanamkan maka semakin banyak pula hak suara yang dimilikinya. Dengan demikian, dapat terjadi seorang pemegang saham mempunyai suara mayoritas dan menentukan dalam setiap proses pengambilan keputusan. Hal yang demikian khas demokrasi model Barat yang bercorak individualistik, bukan demokrasi yang bercorak kebersamaan atau kekeluargaan seperti sistem musyawarah. ${ }^{25}$

Pemegang saham mempunyai suara mayoritas dan menentukan dalam setiap proses pengambilan keputusan pada tataran konkrit sejalan dengan penjelasan Teguh Priadi selaku direktur PT Warajaya Indonesia (sebagai salah satu sampel tulisan ini) yang mengemukakan bahwa perseroan terbatas bercorak individual bukan bercorak kolektif, pemegang saham mayoritas sangat menentukan dalam setiap pengambilan keputusan. Hal itu karena perseroan terbatas didirikan berdasarkan modal yang telah ditanamkan oleh pemegang saham mayoritas sebagai kumpulan

${ }^{23} \mathrm{R}$ Wiryono dalam Tom Gunadi, Sistem Perekonomian ..... Op. Cit., hlm. 79.

${ }^{24}$ Pandji Anoraga, BUMN, Swasta dan Koperasi (Tiga Pelaku Ekonomi), (Jakarta: Dunia Pustaka Jaya, 1995), hlm. 138.

${ }^{25}$ Agus Sardjono, "Asas Kekeluargaan dalam Undang-Undang Perseroan Terbatas," Jurnal Hukum dan Pembangunan Fakultas Hukum Universitas Indonesia, Edisi Reformasi, No. 1-3, Tahun XXVIII, Januari-Juni 1998, hlm. 37. 
modal. Sifat-sifat kekeluargaan dari suatu bangun usaha hanya relevan jika dikaitkan dengan koperasi sebagai salah satu bentuk organisasi ekonomi, sedangkan pada bentuk-bentuk usaha perseroan yang berlaku adalah prinsip one share one vote. ${ }^{26}$

Menurut Jimly Asshidiqie, prinsip one share one vote tersebut memberikan penghargaan yang sangat tinggi terhadap pemilik (property), yakni sama tingginya dengan penghargaan terhadap kebebasan (freedom). Hal ini tercermin dalam cara pandang masyarakat modern yang sangat mengagungkan prinsip liberty dan property. ${ }^{27}$

Undang-Undang Nomor 40 Tahun 2007 tentang Perseroan Terbatas menawarkan sistem musyawarah yang lebih menempatkan kepentingan bersama daripada kepentingan individu. Dengan demikian, dalam perseroan dasar pengambilan keputusan RUPS mestinya juga bukan kepentingan pemodal melainkan kepentingan bersama, tidak saja kepentingan para pemodal tetapi juga semua pihak yang terlibat di dalam perseroan.

Undang-Undang Nomor 40 Tahun 2007 tentang Perseroan Terbatas jika ditelaah tidak dilandasi dengan asas kekeluargaan. Misalnya dengan mulai dibukanya pasar uang dan modal yang berbentuk perseroan terbatas dimiliki oleh orang-orang yang tidak saling mengenal maka tidak mudah melaksanakan semangat kekeluargaan dalam mengelola perusahaan. Para pemegang saham menjual dan membeli saham di pasar uang dan modal, terutama lebih dipengaruhi oleh kemampuan perusahaan menghasilkan keuntungan. Mengenai asas dan semangat kekeluargaan sepenuhnya diserahkan kepada manajer perusahaan yang bersangkutan. ${ }^{28}$

\section{Perbedaan Asas Kekeluargaan Antara Koperasi dan Perseroan Terbatas \\ Perbedaan antara koperasi dan perseroan terbatas tidak hanya terletak pada landasan dan asasnya, tetapi juga prinsip-prinsip pengelolaan organisasi dan usaha yang dilaku- kannya. ${ }^{29}$ Prinsip-prinsip pengelolaan organisasi dan usaha koperasi merupakan penjabaran lebih lanjut dari asas kekeluargaan yang dianut oleh koperasi. Prinsip-prinsip koperasi ini biasanya mengatur hubungan antara koperasi dan para anggotanya, hubungan antara sesama anggota}

${ }^{26}$ Wawancara dengan Teguh Priadi Direktur PT Warajaya Indonesia tanggal 11 Oktober 2013.

${ }^{27}$ Jimly Asshidiqie, Konstitusi Ekonomi, (Jakarta: Kompas Media Nusantara, 2010), hlm. 249.

${ }^{28}$ Mubyarto, Keadilan Sosial dan ..... Op. Cit., hlm. 77.

${ }^{29}$ Tom Gunadi, Sistem Perekonomian ..... Op. Cit., hlm. 87. 
koperasi, pola kepengurusan organisasi koperasi, dan mengenai tujuannya yang ingin dicapai koperasi sebagai lembaga ekonomi yang berasaskan kekeluargaan.

Persamaannya adalah keduanya mempunyai motif ekonomi dan bagaimana posisi masing-masing dalam sistem.

Jimly Asshidiqie berpendapat usaha bersama dengan asas kekeluargaan yang dapat dipahami dalam pengertian yang luas harus pula tercermin dalam satuan-satuan pelaku usaha. Usaha bersama dalam pengertian yang makro harus juga tercermin dalam pengertian yang mikro. Karena itu, prinsip koperasi dan usaha bersama juga dapat dilihat sebagai prinsip kejiwaan yang bersifat koperatif. Dengan menyatakan bahwa koperasi merupakan bentuk usaha yang paling sesuai, tidak berarti bentuk-bentuk lain seperti perseroan terbatas dan BUMN dianggap tidak sesuai. Artinya, yang terpenting semua bentuk-bentuk usaha koperasi, perseroan, dan/atau badan usaha milik negara selalu harus berjiwa koperasi yang di dalamnya terdapat usaha bersama berdasarkan asas kekeluargaan. $^{30}$

Berseberangan dengan pendapat Mubyarto yang mengatakan dapatkah secara realitis mengharapkan demikian? Misalnya dengan mulai dibukanya pasar uang dan modal yang memungkin perusahaan yang berbentuk perseroan terbatas dimiliki orang-orang yang tidak saling mengenal, maka tidak akan mudah melaksanakan semangat kekeluargaan dalam mengelola perusahaan. Para pemegang saham menjual dan membeli saham di pasar uang dan modal, terutama lebih dipengaruhi oleh kemampuan perusahaan menghasilkan keuntungan. Mengenai asas dan semangat kekeluargaan sepenuhnya diserahkan kepada manajer perusahaan yang bersangkutan. ${ }^{31}$

\section{Penutup}

Asas kekeluargaan dalam Undang-Undang Nomor 17 Tahun 2012 tentang Perkoperasian relevan dengan usahanya yang mengutamakan kemakmuran anggota pada khususnya dan masyarakat pada umumnya, bukan kemakmuran orangperseorangan. Ukuran selanjutnya akan tampak dari isi pasal-pasal dalam Undang-Undang Nomor 17 Tahun 2012 tentang Perkoperasian yang secara konsisten berdasarkan nilai dan prinsip kekeluargaan sebagaimana ditentukan dalam Pasal 5 ayat (1) huruf a terutama menyangkut hak dan kewajiban dari pada anggota. Kemudian Pasal 35 Undang-Undang Nomor 17 Tahun 2012 tentang Perkoperasian menem-

${ }^{30}$ Jimly Asshidiqie, Konstitusi ..... Op. Cit., hlm. 270-271.

${ }^{31}$ Mubyarto, Keadilan Sosial dan ..... Op. Cit., hlm. 76. 
patkan sistem musyawarah dalam pengambilan keputusan. Sistem musyawarah ini lebih menempatkan kepentingan bersama daripada kepentingan individu. Sistem musyawarah yang bersumber dari asas kekeluargaan memberikan alternatif yang mungkin lebih baik. Kemudian Undang-Undang Nomor 40 Tahun 2007 tentang Perseroan Terbatas, bila amati ternyata pasal-pasal di dalam undang-undang perseroan terbatas tidak berbeda prinsipnya dengan Wet van Kophandel (WvK) atau Kitab Undang-Undang Hukum Dagang (KUHD), terutama yang menyangkut hak-hak dan wewenang pemegang saham maupun dalam pengaturan berkenaan dengan RUPS.

Sistem quorum dan sistem one share one vote ternyata lebih dekat kepada sistem individualistik lawan dari kekeluargaan. Selain itu, dibukanya pasar uang dan modal memungkinkan perusahaan yang berbentuk perseroan terbatas dimiliki orang-orang yang tidak saling mengenal, maka tidak akan mudah melaksanakan semangat kekeluargaan dalam mengelola perusahaan. Oleh karena itu, disarankan penyesuaian asas kekeluargaan dengan adanya sistem quorum dan sistem one share one vote. Kemudian disarankan penyelarasan asas kekeluargaan berkaitan dengan dibukanya pasar uang dan modal sebagai salah penyertaan modal dan kepemilikan dalam perseroan terbatas.

\section{Daftar Pustaka}

Achmad Ichsan. 1986. Dunia Usaha Indonesia. Jakarta: Pradnya Paramita.

Agus Sardjono. 1998. "Asas Kekeluargaan dalam UndangUndang Perseroan Terbatas," Jurnal Hukum dan Pembangunan Fakultas Hukum Universitas Indonesia, Edisi Reformasi, No. 1-3, Tahun XXVIII, JanuariJuni.

Badan Pembinaan Hukum Nasional. 2003. Laporan Akhir Tim Analisis dan Evaluasi Hukum tentang Bentuk-Bentuk Badan Usaha di Luar Perusahaan Terbatas dan Koperasi. Jakarta: Badan Pembinaan Hukum Nasional.

Bernhard Limbong. 2011. Ekonomi Kerakyatan dan Nasionalisme Ekonomi. Jakarta: Pustaka Margaretha.

Chatamarrasjid. 2000. Menyikapi Tabir Perseroan Terbatas (Piercing The Corporate Veil) Kapita Selekta Hukum Perusahaan. Bandung: Citra Aditya.

Djoko Dwiyanto dan Ignas G Saksono. 2011. Ekonomi (Sosialis) Pancasila Vs Kapitalisme: Nilainilai Tradisional Non Tradisional dalam Pancasila. Yogyakarta: Keluarga Besar Marhaenis DIY.

Hans H Munkner. 2012. 10 Lectures of Co-operatif Law (10 Kuliah Mengenai Hukum Koperasi). 
Alih Bahasa A Hendriques. Jakarta: Rekadesa.

I.G. Rai Widjaya. 2003. Hukum Perusahaan. Jakarta: Megapoin.

Jimly Asshidiqie. 2010. Konstitusi Ekonomi. Jakarta: Kompas Media Nusantara.

Tom Gunadi. 1985. Sistem Perekonomian Menurut Pancasila dan UUD'45. Bandung: Angkasa

Mubyarto. 2005. Keadilan Sosial dan Ekonomi Pancasila, dalam Pemikiran dan Permasalahan Ekonomi di Indonesia dalam Setengah Abad Terakhir, Buku 3 (1966-1982) Paruh Pertama Ekonomi Orde Baru. Yogyakarta: Kanisius.

Padmo Wahjono, Dasar-dasar Demokrasi Ekonomi Kita, (Suatu Tinjauan dari Segi Ketatanegaraan), Makalah disampaikan dalam Panel Diskusi di FH-UNTAR, 1990.

Pandji Anoraga. 1995. BUMN, Swasta dan Koperasi (Tiga Pelaku Ekonomi). Jakarta: Dunia Pustaka Jaya.

Pemikiran dan Permasalahan Ekonomi di Indonesia (buku 3 1966-
1982) Paruh Pertama Ekonomi Orde Baru, (Yogyakarta: Kanisius kerjasama dengan ISEI, 2005.

Ratnawati Prosodjo, RUU tentang Usaha Perseorangan dan Badan Usaha Bukan Badan Hukum, Makalah disampaikan pada acara Sosialisasi RUU Usaha Perseorangan dan Badan Usaha Bukan Badan Hukum, diselenggarakan oleh Direktorat Jenderal Peraturan PerundangUndangan Depar-temen Hukum dan HAM RI di Hotel Kartika Chandra-Jakarta, 2007.

Rudhi Prasetya. 1996. Kedudukan Mandiri Perseroan Terbatas. Bandung: Citra Aditya Bakti.

Sri Edi Swasono. 1987. Membangun Sistem Ekonomi Nasional, Sistem Ekonomi dan Demokrasi Ekonomi. Jakarta: UI Press.

, "Pasal 33 UUD 1945 Harus dipertahankan, Jangan diubah, Boleh ditambah Ayat," Jurnal Perencanaan Pembangunan, Nomor 26, Tahun 2002. 